$\xi=$ 粗

\title{
Evaluation of vegetative and yield attributes of okra (Abelmoschus esculentus (L.) Moench) for adaptation in Anambra State, Nigeria
}

\author{
C.V. Ilodibia ${ }^{1 *}$, N. A. Igboabuchi ${ }^{2}$, W.C. Onwuachu ${ }^{2}$ \\ ${ }^{1}$ Department of Botany, Nnamdi Azikiwe University, P. M. B 5025, Awka, Anambra State, Nigeria \\ ${ }^{2}$ Department of Biology, Nwafor Orizu College of Education Nsugbe, Anambra State, Nigeria \\ *Corresponding author E-mail:Chinyereokafor206@yahoo.com
}

\begin{abstract}
Okra, Abelmoschus esculentus (L.) MOENCH, a fasting growing annual herb, cultivated for its young fruit and valued as an important vegetable in tropical and sub- tropical regions. Adequate production of okra is yet to be achieved especially in Anambra State due to certain factors such as non- utilization of improved cultivar, environmental conditions and inadequate cultural practices. Due to the importance of this vegetable to Nigerian diet, sustainable production is adequate to meet up with the increasing population and the country's economic recession. Vegetative and yield attributes of five cultivars of okra were evaluated for adaptation in Anambra State during 2014/2015 cropping season at the Department of Agricultural Education Teaching and Research Farm, Nwafor Orizu College of Education Nsugbe, Anambra State. A randomized complete block design, replicated three times was used. The results were statistically analyzed using ANOVA. Results showed significant differences $(\mathrm{P}<0.05)$ among the cultivars evaluated in both vegetative and yield attributes. Cultivar LD-88 had higher yield when compared to other cultivars evaluated. It is therefore recommended to farmers for sustainable okra production in the study area.
\end{abstract}

Keywords: Attributes; Okra; Vegetative and Yield.

\section{Introduction}

Okra, Abelmoschus esculentus (L.) MOENCH, a fasting growing annual herb, cultivated for its young fruit and valued as an important vegetable in tropical and sub- tropical regions. It is one of the most commercial and prominent vegetables grown and used extensively for soup in Nigeria (Dinakin et al. 1990). It is a fruit vegetable of national importance and is produced and consumed in all ecological zones of Nigeria (Agbogidi and Nweke 2005). Okra is a vegetable valued for many of its properties. The fruits are used in making soups, salad and for flavouring when dried and powdered (Olarewaju et al. 1997). The tender fruits contain minerals, especially calcium, magnesium, iron, phosphorus, protein, vitamin A, C and riboflavin as well as high mucilage (Ndaeyo et al. 2005). It contains $20 \%$ edible oil and helps to neutralize acid substance, thereby preventing constipation and other stomach disorders (Akoma 1985). The dried pods are used as soup thickeners or used in stew and mature pods produced fibre which is used in paper making and for textile. The stem is used as cooking fuel when dried or as support for climbing crops (Tindall 1986).

In spite of the numerous nutritive potentials of this vegetable, its volume of production is still very low especially in Anambra State. This could be attributed to non- utilization of improved cultivars and inadequate cultural practices (Dinakin et al. 1990). Odeleye and Odeleye (2001) reported that differences in the yield of crops may be due to the genetic diversity and genetic make up. Okra shows high variability in its vegetative and fruit characters (Shoba and Mariappa 2007). According to Ariyo and Akeriova (1986), there were many lines of okra, each with striking uniformity suggesting that okra population has a wide genetic base. In Nigeria, most of the cultivars available to farmers are low yielding local cultivars. There is therefore the need to identify cultivars that would perform better in term of yield in Anambra State to replace the low-yielding local cultivars especially now that the country is facing a great economic recession. This study was undertaken to evaluate the vegetative and yield attributes of okra cultivars in Anambra State, Nigeria.

\section{Materials and methods}

\subsection{Study area}

The experiment was carried out at the teaching and research farm of Department of Agricultural Education, Nwafor Orizu College of Education Nsugbe, Anambra State $\left(6^{0} 25 \mathrm{~N}^{\prime}, 6^{0} 82 \mathrm{E}^{\prime}\right)$ during the $2014 / 2015$ cropping seasons. Nsugbe is located in the tropical rainforest zone with an annual rainfall ranging from $1,500 \mathrm{~mm}$ to $2,000 \mathrm{~mm}$ and are characterized by a bimodal rainfall pattern that peaks in July and September with a short dry spell in August.

\subsection{Collection of plant materials}

The dried pods of five early maturing okra cultivars used in this study were obtained from Federal University of Agriculture, Umudike, Abia State. The okra cultivars were subjected to viability test before used for the experiment. The experiment was laid out in a randomized complete block design with three replications. 


\subsection{Land preparation and sowing}

Site for raising seedlings was cleared using matchet and trashes packed off and burned, a nursery bed of $2.4 \mathrm{~m} \times 3.0 \mathrm{~m}$ and $0.5 \mathrm{~m}$ apart were measured using measuring tape, measuring rope and pegs and prepared to a fine tilt. Farm yard manure at the rate of $30 \mathrm{t} /$ ha was incorporated during this exercise. 3 seeds per stand were sown at a spacing of $40 \mathrm{~cm} \times 60 \mathrm{~cm}$ and later thinned to one seedling per stand. Plots were kept weed free throughout the experiment. Hoeing and hand pulling methods were used.

\subsection{Data collection}

Data collected include number of leaves per plant, plant height, total leaf area, number of pods and fresh pod weight. Data collected were subjected to the analysis of variance (ANOVA) using SAS (2003) and treatment means were separated using Duncan multiple range test at $5 \%$ level of probability.

\section{Results and discussion}

The results are shown in Tables 1- 4

The result revealed significant differences among the cultivars in plant height across the weeks (Table 1). Cultivar TAE 38 showed superiority over the other cultivars in plant height at 8,10 and $12 \mathrm{WAP}$ with the highest value of $102.90 \mathrm{~cm}$; this was followed by LD-88 with the value of $99.48 \mathrm{~cm}$. this is in with the work of Ibrahim et al. (2000), who reported that differences in growth indices of crops was attributed to their genetic make - up. Result on the number of leaves indicated that there was gradual increase in number of leaves among the cultivars from $2 \mathrm{WAP}$ with the peak at $8 \mathrm{WAP}$ after which the number of leaves started to decrease gradually across the cultivars. Cultivar TAE 38 had the highest number of leaves at $8 \mathrm{WAP}$ with the value of 10.32 , followed by LD-88 with the value of 9.64 (Table 2). Significant differences were not observed among the five cultivars tested in total leaf area, except on $2 \mathrm{WAP}$ and 4WAP (Table 3 ). Although the cultivars showed no significant different at $8 \mathrm{WAP}$, cultivars TAE 38 and LD- 88 had the highest total leaf area of $1,362.16 \mathrm{~cm}^{2}$ and $1,272.54 \mathrm{~cm}^{2}$ respectively. This indicated that the peak growth of cultivars in total leaf area was at 8 WAP (Table 3 ). These observations are in line with the work of Muoneke and Aliyu (1997), who reported increase in the leaf area index of three okra cultivars in the course of the plant growth up to 70 DAP, and thereafter declined. The result revealed also that the five cultivars differ significantly from one another in the fresh number of pods and fresh pod weight. This is in conformity with Ilodibia et al. (2013) who reported that yield of cowpea varies from one variety to another. Also in line with the work of Odeleye and Odeleye (2001) who reported that differences in yield of crops may be attributed to the cultivar grown, environmental condition and genetic make - up. Cultivar LD-88 recorded the highest number of pods and fresh pod weight with values of 4.53and 9.98respectively (Table 4).

This could be attributed to efficient conversion of assimilate to pod weight by this cultivar.

\begin{tabular}{lllllll}
\multicolumn{7}{l}{ Table 1: Variability on plant height of okra cultivars } \\
\hline $\begin{array}{l}\text { okra } \\
\text { cultivar }\end{array}$ & $2 \mathrm{WAP}$ & $4 \mathrm{WAP}$ & $6 \mathrm{WAP}$ & $8 \mathrm{WAP}$ & $10 \mathrm{WAP}$ & $12 \mathrm{WAP}$ \\
\hline $\begin{array}{l}\text { NHAe- } \\
47.4\end{array}$ & $3.80^{\mathrm{ab}}$ & $5.91^{\mathrm{ab}}$ & $14.85^{\mathrm{c}}$ & $32.90^{\mathrm{ab}}$ & $58.82^{\mathrm{ab}}$ & $77.23^{\mathrm{c}}$ \\
LD-88 & $3.35^{\mathrm{b}}$ & $5.36^{\mathrm{bc}}$ & $16.05^{\mathrm{ab}}$ & $35.61^{\mathrm{ab}}$ & $66.33^{\mathrm{a}}$ & $99.48^{\mathrm{b}}$ \\
V.35 & $4.44^{\mathrm{ab}}$ & $6.40^{\mathrm{a}}$ & $17.78^{\mathrm{a}}$ & $33.38^{\mathrm{b}}$ & $54.89^{\mathrm{b}}$ & $75.64^{\mathrm{c}}$ \\
V.104 & $4.70^{\mathrm{a}}$ & $6.16^{\mathrm{ab}}$ & $16.65^{\mathrm{ab}}$ & $35.62^{\mathrm{a}}$ & $60.37^{\mathrm{ab}}$ & $93.38^{\mathrm{bc}}$ \\
TAE 38 & $3.35^{\mathrm{b}}$ & $5.20^{\mathrm{b}}$ & $\mathrm{I} 6.46^{\mathrm{ab}}$ & $37.02^{\mathrm{a}}$ & $71.50^{\mathrm{ab}}$ & $102.90^{\mathrm{a}}$ \\
\hline
\end{tabular}

WAP: Weeks after planting.

Means in the same column followed by the same letters are not significantly different at $\mathrm{p}=0.05 \mathrm{using} \mathrm{DMRT}$
Table 2: Variability on the number of leaves of okra cultivars

\begin{tabular}{lcccccc}
\hline $\begin{array}{l}\text { okra } \\
\text { cultivar }\end{array}$ & 2 WAP & 4 WAP & 6 WAP & 8 WAP & $10 \mathrm{WAP}$ & $12 \mathrm{WAP}$ \\
\hline $\begin{array}{l}\text { NHAe- } \\
47.4\end{array}$ & $4.06^{\mathrm{a}}$ & $6.01^{\mathrm{a}}$ & $9.21^{\mathrm{a}}$ & $9.59^{\mathrm{a}}$ & $8.24^{\mathrm{a}}$ & $7.23^{\mathrm{a}}$ \\
LD-88 & $4.07^{\mathrm{a}}$ & $6.13^{\mathrm{a}}$ & $9.37^{\mathrm{a}}$ & $9.64^{\mathrm{a}}$ & $8.83^{\mathrm{a}}$ & $7.38^{\mathrm{a}}$ \\
V.35 & $4.15^{\mathrm{a}}$ & $6.14^{\mathrm{a}}$ & $9.30^{\mathrm{a}}$ & $9.28^{\mathrm{a}}$ & $8.15^{\mathrm{a}}$ & $7.44^{\mathrm{a}}$ \\
V.104 & $4.08^{\mathrm{a}}$ & $6.11^{\mathrm{a}}$ & $8.65^{\mathrm{a}}$ & $9.07^{\mathrm{a}}$ & $8.37^{\mathrm{a}}$ & $6.38^{\mathrm{a}}$ \\
TAE 38 & $4.27^{\mathrm{a}}$ & $6.30^{\mathrm{a}}$ & $9.36^{\mathrm{a}}$ & $10.32^{\mathrm{a}}$ & $8.50^{\mathrm{a}}$ & $6.90^{\mathrm{a}}$ \\
\hline
\end{tabular}

WAP: Weeks after planting.

Means in the same column followed by the same letters are not significantly different at $\mathrm{p}=0.05 \mathrm{using}$ DMRT

Table 3: Variability on total leaf area $\left(\mathrm{cm}^{2}\right)$ of okra cultivars

\begin{tabular}{lcccccc}
$\begin{array}{l}\text { okra } \\
\text { cultivar }\end{array}$ & 2 WAP & 4 WAP & 6 WAP & 8 WAP & 10 WAP & 12 WAP \\
\hline $\begin{array}{l}\text { NHAe- } \\
47.4\end{array}$ & $29.10^{\mathrm{c}}$ & $48.97^{\mathrm{b}}$ & $523.45^{\mathrm{a}}$ & $1,196.34^{\mathrm{a}}$ & $586.30^{\mathrm{ab}}$ & $546.62^{\mathrm{a}}$ \\
LD-88 & $38.85^{\mathrm{bc}}$ & $117.39^{\mathrm{a}}$ & $482.45^{\mathrm{a}}$ & $1,272.54^{\mathrm{a}}$ & $688.80^{\mathrm{a}}$ & $582.85^{\mathrm{a}}$ \\
V.35 & $57.38^{\mathrm{a}}$ & $148.90^{\mathrm{a}}$ & $514.17^{\mathrm{a}}$ & $1,123.14^{\mathrm{a}}$ & $842.80^{\mathrm{a}}$ & $494.55^{\mathrm{a}}$ \\
V.104 & $39.60^{\mathrm{bc}}$ & $95.01^{\mathrm{ab}}$ & $589.62^{\mathrm{a}}$ & $1,175.82^{\mathrm{a}}$ & $869.57^{\mathrm{a}}$ & $611.48^{\mathrm{a}}$ \\
TAE 38 & $37.03^{\mathrm{b}}$ & $94.60^{\mathrm{ab}}$ & $503.14^{\mathrm{a}}$ & $1,362.16^{\mathrm{a}}$ & $770.62^{\mathrm{a}}$ & $695.19^{\mathrm{a}}$ \\
& & & & & & \\
\hline
\end{tabular}

WAP: Weeks after planting.

Means in the same column followed by the same letters are not significantly different at $\mathrm{p}=0.05$ using DMRT

Table 4: Variability on the number of pods and fresh weight of okra cultivars

\begin{tabular}{llllllll}
$\begin{array}{l}\text { okra } \\
\text { cultivar }\end{array}$ & $\begin{array}{l}\text { No. of } \\
\text { pods } \\
10 W A P\end{array}$ & $\begin{array}{l}\text { No. of } \\
\text { pods } \\
12 W A P\end{array}$ & $\begin{array}{l}\text { No. of } \\
\text { pods } \\
14 W A P\end{array}$ & $\begin{array}{l}\text { FW. of } \\
\text { Pods } \\
(\mathrm{kg}) \\
10 \mathrm{WAP}\end{array}$ & $\begin{array}{l}\text { FW. of } \\
\text { Pods } \\
(\mathrm{kg}) \\
12 \mathrm{WAP}\end{array}$ & $\begin{array}{l}\text { FW. of } \\
\text { Pods(kg) } \\
14 W A P\end{array}$ \\
\hline $\begin{array}{l}\text { NHAe- } \\
47.4\end{array}$ & $2.14^{\mathrm{a}}$ & $2.78^{\mathrm{ab}}$ & $2.66^{\mathrm{a}}$ & $3.09^{\mathrm{ab}}$ & $6.40^{\mathrm{b}}$ & $7.13^{\mathrm{ab}}$ \\
LD-88 & $2.40^{\mathrm{a}}$ & $4.53^{\mathrm{a}}$ & $2.33^{\mathrm{ab}}$ & $4.26^{\mathrm{a}}$ & $8.00^{\mathrm{a}}$ & $9.98^{\mathrm{a}}$ \\
V.35 & $1.69^{\mathrm{a}}$ & $2.10^{\mathrm{b}}$ & $1.69^{\mathrm{bc}}$ & $2.16^{\mathrm{b}}$ & $4.05^{\mathrm{c}}$ & $5.44^{\mathrm{c}}$ \\
V.104 & $1.66^{\mathrm{a}}$ & $2.22^{\mathrm{b}}$ & $2.05^{\mathrm{ab}}$ & $2.10^{\mathrm{b}}$ & $6.21^{\mathrm{b}}$ & $5.08^{\mathrm{c}}$ \\
TAE 38 & $1.52^{\mathrm{a}}$ & $2.41^{\mathrm{ab}}$ & $2.41^{\mathrm{a}}$ & $1.05^{\mathrm{c}}$ & $7.03^{\mathrm{ab}}$ & $6.20^{\mathrm{b}}$ \\
\hline
\end{tabular}

FW: fresh weight

Means in the same column followed by the same letters are not significantly different at $\mathrm{p}=0.05 \mathrm{using}$ DMRT

\section{Conclusions}

The differences observed among the cultivars evaluated showed that okra has a broad genetic base with high level of variability, which can be used by plant breeders in okra improvement programme. Cultivar LD-88 performed better than other cultivars in yield attributes, indicating its better adaptation to the environmental condition in Anambra State, Nigeria.

\section{References}

[1] Agbogidi OM, Nweke FU (2005) Impact of Gas Flaring on the Growth and Yield of Okra (Abelmoschus Esculentus) In Delta State. Proc. of the $39^{\text {th }}$ Annual Conference of Agricultural Society of Nigeria.321-322.

[2] Akoma UM (1985) Soil Organic Matter and its Conservation for Increase in Productivity of Vegetables in Nigeria. University of Ife Press.

[3] Ariyo OJ, Akenova ME (1986) Evaluation of Varieties of Okra for Distinctiveness and Uniformity. Nig J. Agron 1: 97-102.

[4] Dinakin MN, Lawal SA, Ogunfowara T, Okundalaye O (1990) Evaluation and Characterization of Okra Germplasm. NIHORT Annual Report, Vegetable Programme.

[5] Ibrahim K, Amans A, Abubakar IU (2002) Growth Indices and Yield of Tomato Varieties as Influenced by Crop Spacing at Samara. Proc. of the $18^{\text {th }}$ Hortson Conference, 1: 40-47.

[6] Ilodibia CV, Egboka TP, Okeke NF, Ezeabara CA (2013)Determination of Growth and Productivity of Selected Cowpea Varieties in Ultisols of South Eastern Nigeria, Nig $J$. Agri.44(2): 211-216. 
[7] Muoneke CO, Aliyu EA (1997) Responses of Okra to Plant Density and Pattern of Plant Arrangement in Nigeria, Indian J.AgriSci, 61: 726-730

[8] Ndaeyo NU, Edu SU, John NM (2005) Performance of Okra as Affected by Organic and Inorganic Fertilizers on Ultisol. Proc. of the $39^{\text {th }}$ Annual Conference of Agricultural Society of Nigeria.206-209.

[9] Odeleye FO, Odeleye OM (2001) Evaluation of Morphological and Agronomic Characteristics of Two Exotic and two Adapted Varieties of Tomato in South West, Nigeria, Proc. of the $19^{\text {th }}$ Annual Conference of Hortson Conference, 28-30.

[10] Olarewaju JD, Yeye MY, Alibi SO (1997) Performance of Improved Varieties of Okra in the Northern Guinea Savanna, Proc. of the $15^{\text {th }}$ Annual Conference of Hortson Conference; 78-80.

[11] SAS (2003) Statistical Analysis System. SAS Release 9-1 for Windows; SAS Institute Inc Cary Nc. USA.

[12] Shoba K, Mariappa S (2007) Heterosis Studies in Okra for Some Important Biometrical Traits. Acta Hort, 75 (2): 437 440.https://doi.org/10.17660/ActaHortic.2007.752.79.

[13] Tindal HD (1986) Vegetable in the Tropics. $1^{\text {st }}$ ed. Macmillian Publishers Hong Kong, pp. 533. 